\title{
Editorial
}

\section{Sustainable Development: Who cares?}

\author{
WENDY HARCOURT
}

The past months have been deeply perplexing for all concerned with environmental, economic and social justice. Prior to September 11th there was an increasingly widespread and vocal dialogue entering the mainstream about globalization, unfair trade, gender equity, human rights, sustainable agriculture, privatization, social justice movements, democracy, environment, in short, all that comes under the broad banner of sustainable development.

September 11th ushered in a new kind of debate. It allowed, in a major turn around, the mainstream media and the big European and US institutions to force off the 'real agenda' the concerns of environmental activists and social movements. The need to ignore those voices (as they did not go away) was in the name of protecting global security. The predatory nature of multinational corporations, the endemic ill health and poverty of the vast majority of the world, the fragility of the natural world were beginning to attract real concern. Policy-makers and the media were compelled to take on board state and corporate corruption and civic responsibility, the failure to meet the majority of the world's livelihood needs or guarantee their rights, the implications of the collapse of massive Antarctic icebergs for global warming. But now, since September 11th, poverty, rights and environment are safely shelved as sidelines to the major issues of terrorism and security for the nations of the free world.

It is interesting, in terms of helping to dispel at least some discomfort around the failure of putting into place anything like sustainable development, to look at the story of Bjorn Lomborg, a Danish statistician, now elevated to one of the top environmental posts in Denmark. His controversial book The Skeptical Environmentalist (2001) has been welcomed in the new post-September 11th climate. Here, to the pleasure of the powers that be, a liberal Nordic with green credentials was reassuring people that pollution levels were actually falling, that resources were bountiful and that global warming was a non-starter. In the 
post-September 11 th climate the challenge to his data by environmentalists worldwide, and major scientific journals, could be safely ignored. Here was the proof that many wanted - that, in the end, all we need in order to develop is economic growth and technology. Livelihoods for the South are, of course, in this analysis, totally off the map, but then where does terrorism, after all, have to be fought?

However, as this journal issue roundly shows, Lomborg and the media and powers that fete him in Europe and the US cannot carry the day so easily. As they air the grand narratives to secure world prosperity and defeat the terrorism cradled in the poor, undemocratic (read uncivilized) countries of the South, they are continuing to be challenged. There is now a strong and sophisticated movement for social and ecological change that takes on board the facts of human and environmental unsustainable development of the last century. This debate pulls together local and global issues, covers concerns around economics, conflict, futures, trade, nature, culture, gender, quality of life and small level place-based resistance. And unlike Dr Lomborg, most of this resistance, innovation and vision comes not from the lap-tops perched on the desks of northern academe and bureaux, but is emerging from the many places of the South that confront daily the damage of global and local unsustainability.

Just before the anniversary of September 11th, world leaders, governments, environmentalists and social movements will gather together in Johannesburg for the Rio +10 Earth Summit, the World Summit on Sustainable Development. To follow the confused mood of the last months, we can predict a rather meaningless humbling of politicians in the face of yet more statistics of global warming, disappearing forests, polluted waters, sprawling and unsafe cities and the increasing fragility of ecosystems. The poverty and environmental devastation of the South will be noted, and many promises will be made, and world bodies asked to review and suggest action. And millions of ordinary people from Soweto will be out in the streets together with global social and environmental activists, no doubt joined in solidarity by demonstrations in other big cities
But we can also predict that any lamenting at the sorry future we are bequeathing our children will be forgotten immediately as the US leads the world in a massive remembrance day on September 11th. In an instant, sustainable development will be off the agenda. The thousands of poor people who will die that day of hunger, the thousands made ill from polluted waters, the hectares of forests lost and the irreversible loss of ecosystems will not even receive the smallest of paragraphs in the mainstream press and media.

It is important, though, to provide an alternative to this 'realist' and cynical prediction. First of all, as my colleagues living in Africa remind me, the harping on September 11th is a largely western preoccupation. Like the 'end of history' it belies the realities of most of the world - those who live daily with death - whether from war, disease, contamination, conflict, accident, overcrowding, or forced removal from their homes. Such levels of insecurity, such painful and difficult histories and narratives, are not part of the lives of people living in the rich and secure parts of the West. Nor is there an understanding of the rich of the West about their own part in the violence of those millions of lives.

What September 11th just might do, in the cracks left by the mainstream, is to bring home to the West elite that all our lives are interconnected. It is a sad and dangerous illusion to imagine that anyone can safely ignore the levels of poverty, ecological damage and planetary risk the lifestyles of the West are producing. The levels of consumption, the huge ecological footprints of the elite living in the USA, Canada and Europe, Australia and New Zealand are producing situations which foster desperate and dangerous people who engage in dangerous and desperate acts.

But that is still too simple. Going below the surface, on a much more profound scale, consumption and western lifestyles are producing daily pain and death for people in the out-of-the-way places (bodies, homes, communities, workplaces, environments). The articles in the issue document what it is like to live in daily conflict in a damaged and lifethreatening environment. The peoples of the Pacific, the wetlands of Brazil, rural China, Nepal and India are struggling with turbulence and change to their environment, community, culture and being. At the 
same time the journal issue points to the many innovative and successful ways communities are overcoming this, often flying in the face of the big powers, often following a very different rationale from those of the mainstream: the Dalits in Nepal, small NGOs in Ecuador taking on the World Bank, women in localities around the world fighting for their place-based autonomy and rights, activists taking on the big multinational corporations.

The strength of the global world debate and dialogue on sustainable development cannot be weakened in the face of wars against terrorism led by the US administration, European governments and other allies, even if it is off the 'big P' political agenda and no longer given mainstream media time. And it is in these dialogues and debates, through the networking of small groups around the world, that the interconnection between the unthinking consumption of the rich minority and the increasing poverty, ill health and pain of the South is so clearly understood. The conviviality among these peoples is in sharp contrast with 'us and them', the bully boy tactics of those in power.

What is pointedly different is the level of political will. As Jorge Nieto Montesino argues, it is the quality of the political will that will make the difference for environmental, economic and social justice. And the political will has to come from the realities of the majority, the new types of politics forming 'in places', not imposed from above.

In Johannesburg, as Thais Corrall, Sacha MullerKraenner and Ashok Khosla and the experience of Durban and the World Conference Against Racism held last year suggest, there will be very different actors and agendas than in Rio. Civil society will not be knocking on the doors, it will be there as one of the main players inside and outside the auditoria. The issue of consumption, lifestyle of the rich, gender equality, globalization, new ways to organize work, communicate through networks, connect national and community and place-based rights, will all be part of the agenda. The question is, when the next day the US super-power, policymakers and media ignore all that has been said and done, will it truly matter? There are other loci of power and strength that do not completely rely on US and European dominated global capitalism. And it is in these new institutions that we are creating, from positions of knowledge and strength, ways to challenge dominant powers to fight against ill health, violence and poverty and celebrate, with Carlos Zorrilla and his children, the beauty of the Ecuadorian cloud forests.

\section{Reference}

Lomborg, B. (2001) The Skeptical Environmentalist: Measuring the Real State of the World. Cambridge: Cambridge University Press.

development is abstracted in Cab Abstracts, Communication Abstracts, Environmental Abstracts, GEOBASE, Geo Abstracts: Human Geography, HRI Reporter, International Development Abstracts, International Labour Documentation, International Political Science Abstracts, Social Services Abstracts, Sociofile and Sociological Abstracts; and is indexed in CSA Political Science \& Government, Econlit, Environmental Abstracts, International Bibliography of the Social Sciences, Journal of Economic Literature, OCLC Public Affairs Information Service. 